\title{
Business Meetings of Each Society
}

\section{Executive Committee of ISLSM}

November $29^{\text {th }}, 13: 00 \sim 15: 00$, Room-A (CHITOSE), MEIJI-KINENKAN

\section{Executive Committee of WFSLMS}

November $29^{\text {th }}, 15: 00 \sim 18: 00$, Room-A (CHITOSE), MEIJI-KINENKAN

\section{General Assembly of ISLSM}

November $30^{\text {th }}, 12: 10-13: 00$, Room-A (RURI-WEST), HOTEL GRAND HILL ICHIGAYA

\section{General Assembly of WFSLMS}

December $1^{\text {st }}, 12: 10-13: 00$, Room-A (RURI-WEST), HOTEL GRAND HILL ICHIGAYA

\section{Social Program}

\section{TOKYO BAY CRUISING}

November $30^{\text {th }}, 19: 00-21: 30$

NOTE: The Shuttle buses to Hinode Terminal Office will leave Hotel Grand Hill ICHIGAYA at 18:00.

Please bring your invitation cards and wear your identification badges while you are attending the TOKYO BAY CRUISING.

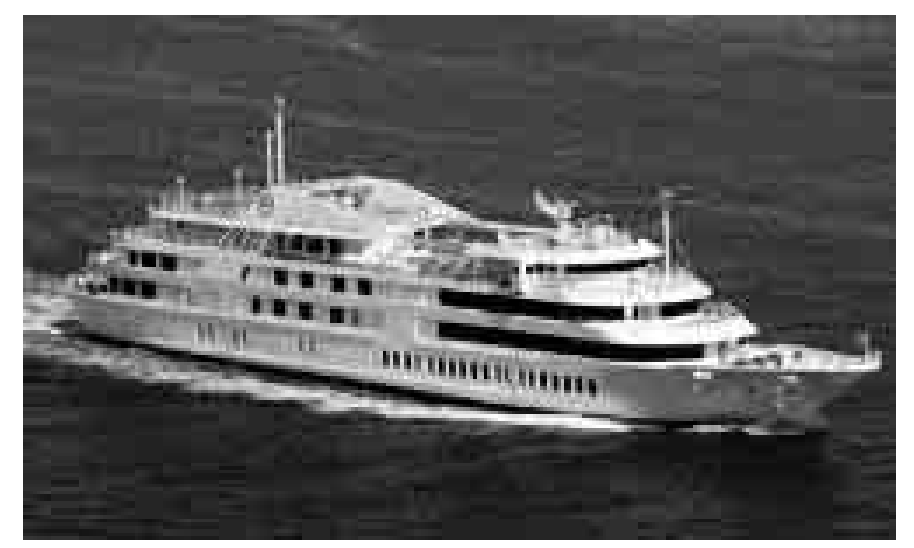

\section{GALA DINNER OF JAPAN SOCIETY FOR LASER SURGERY AND MEDICINE}

December $2^{\text {nd }}, 18: 30$ - 20:30, ROOM-A,B,C(RURI), HOTEL GRAND HILL ICHIGAYA 